University of Nebraska - Lincoln

DigitalCommons@University of Nebraska - Lincoln

2013

Fostering Climate Change Education in the Central Great Plains: A

Public Engagement Approach

Lisa M. PytlikZillig

Timothy Steffensmeier

Amber Campbell Hibbs

Ben Champion

Eric Hunt

See next page for additional authors

Follow this and additional works at: https://digitalcommons.unl.edu/lpz

Part of the Administrative Law Commons, Counseling Commons, Dispute Resolution and Arbitration Commons, Family Law Commons, Juvenile Law Commons, Law and Psychology Commons, Law and Society Commons, Psychology Commons, and the Public Law and Legal Theory Commons

This Article is brought to you for free and open access by the Public Policy Center, University of Nebraska at DigitalCommons@University of Nebraska - Lincoln. It has been accepted for inclusion in Lisa PytlikZillig Publications by an authorized administrator of DigitalCommons@University of Nebraska - Lincoln. 


\section{Authors}

Lisa M. PytlikZillig; Timothy Steffensmeier; Amber Campbell Hibbs; Ben Champion; Eric Hunt; John A. Harrington, Jr.; Jacqueline D. Spears; Natalie Umphlett; Tarik Abdel-Monem; Roger Bruning; and Daniel Kahl 
The International Journal of

Sustainability

Education

\section{Fostering Climate Change Education in the Central Great Plains}

\section{A Public Engagement Approach}

LISA M. PYTLIKZILLIG, TIM STEFFENSMEIER, AMBER CAMPBELL HIBBS, BENJAMIN L. CHAMPION, ERIC HUNT, JOHN

HARRINGTON, JR., JACQUELINE D. SPEARS, NATALIE UMPHLETT, TARIK ABDEL-MONEM, ROGER BRUNING AND DANIEL W KAHL 
THE INTERNATIONAL JOURNAL OF SUSTAINABILITY EDUCATION

http://onsustainability.com/

First published in 2013 in Champaign, Illinois, USA

by Common Ground Publishing

University of Illinois Research Park

2001 South First St, Suite 202

Champaign, IL 61820 USA

www.CommonGroundPublishing.com

ISSN: 2325-1212

(C) 2013 (individual papers), the author(s)

(C) 2013 (selection and editorial matter) Common Ground

All rights reserved. Apart from fair dealing for the purposes of study, research, criticism or review as permitted under the applicable copyright legislation, no part of this work may be reproduced by any process without written permission from the publisher. For permissions and other inquiries, please contact <cg-support@commongroundpublishing.com>.

The International Journal of Sustainability Education is a peer-reviewed scholarly journal.

Typeset in CGScholar.

http://www.commongroundpublishing.com/software/ 


\title{
Fostering Climate Change Education in the Central Great Plains: A Public Engagement Approach
}

\author{
Lisa M. PytlikZillig, University of Nebraska-Lincoln, USA \\ Tim Steffensmeier, Kansas State University, USA \\ Amber Campbell Hibbs, Kansas State University, USA \\ Benjamin L. Champion, Kansas State University, USA \\ Eric Hunt, University of Nebraska-Lincoln, USA \\ John Harrington, Jr., Kansas State University, USA \\ Jacqueline D. Spears, Kansas State University, USA \\ Natalie Umphlett, University of Nebraska-Lincoln, USA \\ Tarik Abdel-Monem, University of Nebraska-Lincoln, USA \\ Roger Bruning, University of Nebraska-Lincoln, USA \\ Daniel W Kahl, Kansas State University, USA
}

\begin{abstract}
Despite its increasing importance for sustainability, building widespread competency in the basic principles of climate literacy among the United States general public is a great challenge. This article describes the methods and results of a public engagement approach to planning climate change education in the Central Great Plains of the United States. Our approach incorporated contextual and lay expertise approaches to public engagement with a focus on supporting the self-determination of the specific stakeholder groups-rural producers, educators, and community members. An integration of results from the focus groups reveal that our approach was received positively and elicited a number of important themes describing stakeholders' concerns, interests, and needs pertaining to climate change education. Focus group participants were concerned about climate change, cautious regarding conflicting sources of information, and interested in learning more about climate science and climate change impacts. Across all stakeholder groups, participants consistently expressed a desire for trustworthy, personally-and locally-relevant, easy-to-access information that they could evaluate and use in applications as they saw fit. Although these findings do not yet provide a recipe for concrete educational programming, when viewed through the lenses of social, cognitive and educational theories, they suggest a number of important directions for future research and program implementation that are needed in order to advance the understanding of effective climate change education.
\end{abstract}

Keywords: Climate Change Education, Public Engagement, Community-based Research, Rural Stakeholders, Trust

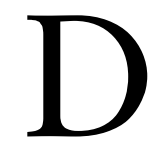

espite its increasing importance for sustainability, building widespread competency in the basic principles of climate literacy is an enormous educational challenge. This challenge has been recognized across continents worldwide, including Africa (United Nations Economic Commision for Africa African Climate Policy Centre, 2011), Europe (Milér \& Sládek, 2011; Uherek \& Schüpbach, 2008) and Australia, as the leaders of many countries consider how to respond to the potential impacts of changes in their climates. Within the Central Great Plains (CGP) of the United States, meeting the challenge is

The International Journal of Sustainability Education

Volume 8, 2013, http://onsustainability.com/, ISSN 2325-1212

(C) Common Ground, Lisa M. PytlikZillig, Tim Steffensmeier, Amber Campbell Hibbs, Benjamin L. Champion, Eric Hunt, John Harrington, Jr., Jacqueline D. Spears, Natalie Umphlett, Tarik Abdel-Monem, Roger Bruning, Daniel W Kahl, All Rights Reserved, Permissions: cg-support@commongroundpublishing.com 
especially important, because the area is heavily involved in food production that could be disrupted by climate changes. Furthermore, recent surveys in the U.S. show marked variability in public knowledge and views about climate change. For example, Leiserowitz and colleagues' work with "Six Americas" has shown that U.S. attitudes toward global warming vary from alarmed to concerned, cautious, disengaged, doubtful, or dismissive (Leiserowitz, 2009; Leiserowitz, Maibach, Roser-Renouf, Smith, \& Hmielowski, 2011; Leiserowitz, Smith, \& Marlon, 2010), and these attitudes correlate with differences in knowledge about climate change (Leiserowitz \& Smith, 2010). Their work also shows a wide gap between expert and public knowledge about climate science, as well as year-to-year variations in public knowledge of climate change and desires to learn more about it.

There are many challenges to increasing public knowledge about climate change. Non-scientific ways of knowing, such as heuristics based on political party affiliation, influence mindsets regarding climate change and cannot be ignored (Dunlap \& McCright, 2008; McCright \& Dunlap, 2011). Other challenges include the complexity of the information about climate change and problems posed by the language of climate science, misconceptions, and inadequate curricula (Dupigny-Giroux, 2010; Hoffman \& Barstow, 2007). Furthermore, uncertainties inherent to the impacts of climate change (J. B. Smith et al., 2009) and implications of climate change on policy development in many sectors (e.g., energy provision, water management, and agriculture), make it important to improve public knowledge in ways that are policy relevant but not policy prescriptive.

Approaches to the challenges of climate education have included studies of and recommendations for engaging the public (Talpin \& Wojcik, 2010), changing mental models of climate change (Bostrom, Morgan, Fischhoff, \& Read, 1994; Harrington, 2008), overcoming heuristic processing (Leiserowitz, 2006; Rachlinski, 2000), using inquiry methods and data visualization to enhance deep understanding (Edelson, 2001), and framing climate change information so that it is relevant to stakeholders who have different values and pre-existing beliefs (Nisbet, 2009; Zia \& Todd, 2010). While all of these approaches are valuable, they do not clearly outline a concrete educational plan for a specific region or group of stakeholders. As noted by Nisbet (2009, p. 22) (with regard to framing), "Additional research using in-depth interviews, focus groups, and sophisticated survey and experimental techniques needs to further explore, identify, and test these frames across audiences" (see also Nisbet \& Mooney, 2007). However, Nisbet's statement applies beyond framing. There is a need to explore, not only the frames that appeal to specific audiences, but also the climate-change-relevant needs, desires, values, and current understandings of specific audiences.

The purpose of this article is to begin to fill the gap in such stakeholder-specific research by describing methods and preliminary results from an effort that, consistent with Nisbet's suggestion, uses focus groups and a public engagement approach to planning climate change education for stakeholders in the CGP region. This article illustrates how public engagement methods can be used to elicit the major concerns of stakeholders from a specific region, which can then be viewed in the light of theory to develop a framework both for planning stakeholder-specific education and conducting programs of research that can advance evidence-based climate change education.

\section{Method}

\section{Approach}

To answer our central questions concerning the educational programs that would be effective for the CGP, we first considered strategies for public engagement. Public engagement models include deficit models, which attempt to correct the public's lack of knowledge (e.g., Ziman, 1991, 1992); contextualist and lay expertise models, which emphasize the need to take into account public values, knowledge, and contexts (e.g., Wynne, 1995); and deliberative models, 
which encourage informed deliberation and discussion (e.g., Fiskin, 1991). Because our goal was to create programs based on the needs of the CGP stakeholders, we took a contextualist and lay expertise approach, emphasizing the importance of stakeholder perceptions, values, beliefs and experiences regarding climate and climate change. We also included consideration of social psychological theories of basic human needs, including Self Determination Theory (Deci \& Ryan, 1987, 2000), which posits three basic needs influencing most human behavior: the need to feel like one belongs and has meaningful relationships with others, or relatedness; the need for competence and mastery over one's environment; and the need for autonomy or self-directed choices.

\section{Participants}

Twenty focus groups were held across Kansas, with a minimum of five separate meetings per targeted stakeholder group (i.e., producers, educators, and community members; see Table 1 for demographics, and Figure 1 for geographic areas represented). Focus group participants were recruited from across Kansas through K-State Research \& Extension agents, personal and professional networks of project team members, and science and agriculture education associations within the state. Although the focus group members were not randomly selected in order to achieve a level of representativeness that would allow generalization of results to the entire populations of the target groups, the demographics in Table 1 do suggest reasonable representation of the diversity in Kansas. For example, compared to population statistics, agricultural producers were somewhat younger than average and composed of proportionally fewer men than in the population (in 2011, the average age of producers in Kansas was 58, and $88 \%$ of farm operators were men); however the ethnic/racial composition of the focus groups came close to the population statistics (Kansas is about $84 \%$ white).

Table 1: Focus Group Participants and Demographics

\begin{tabular}{|l|c|c|c|c|c|}
\hline Stakeholder Group & $\begin{array}{c}N \\
\text { Groups }\end{array}$ & $\begin{array}{c}N \\
\text { Persons }\end{array}$ & $\begin{array}{c}\text { Median } \\
\text { Age }\end{array}$ & $\begin{array}{c}\text { Percent } \\
\text { Male }\end{array}$ & $\begin{array}{c}\text { Percent } \\
\text { White }\end{array}$ \\
\hline Agricultural producers & 5 & 46 & 56 & 70 & 85 \\
\hline Community members & 8 & 66 & 52 & 59 & 91 \\
\hline Educators & 7 & 65 & 35 & 68 & 86 \\
\hline
\end{tabular}




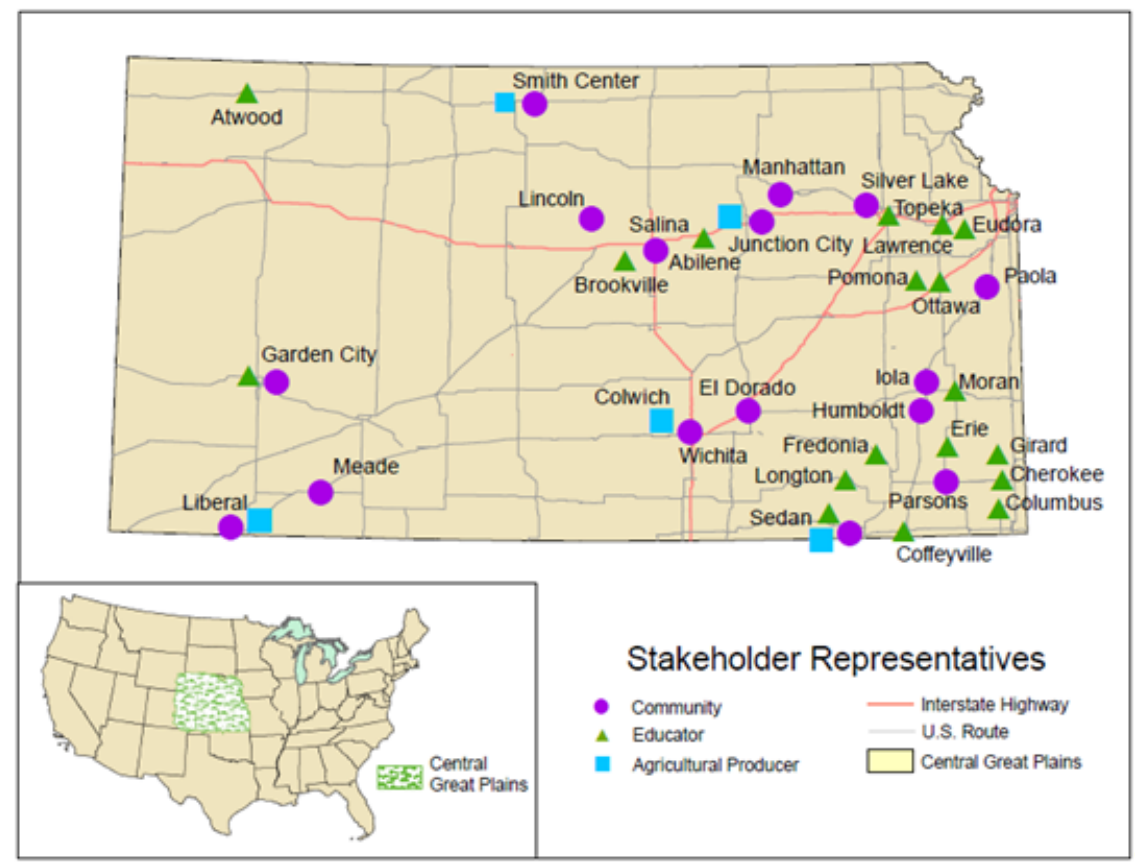

Figure 1: Geographic Locations Represented by Stakeholders Participating in the Focus Groups

\section{Procedures}

The face-to-face focus group meetings, each consisting of 8-20 participants, were conducted separately for each stakeholder group. Each meeting was conducted by a facilitator trained by the Institute for Civic Discourse and Democracy to remain neutral and ensure that all perspectives were heard. In addition, a member of the CGP-Climate Education Partnership (CGP-CEP) leadership team attended each meeting to introduce and field questions about the project.

Given prior work (e.g., Leiserowitz et al., 2011), it seemed likely that participants would represent various and potentially conflicting viewpoints on the Six Americas Spectrum. To create a safe space for conversation, we started each focus group by acknowledging that discussing variations in climate can be rife with tension and strong opinions, and expressed our hope that the meetings would yield learning and partnerships with people on all points of the Six America's Spectrum (i.e., alarmed, concerned, cautious, disengaged, doubtful, or dismissive). Consistent with our desire to support stakeholder self-determination and needs for competence and autonomy, we also affirmed our goal of helping CGP residents become more informed about climate in ways that they valued and would help them meet their goals.

Each 90-120 minute focus group followed a similar structure and script. First, participants were introduced to the CGP-CEP grant project and engaged in an exercise in which they reported anonymously where they fell on the Six Americas Spectrum regarding the topic of climate change. To begin the discussion, the results from the Six Americas exercise were reported on a flipchart to visually illustrate the diversity of opinions in the group. Next, the facilitator asked a series of open-ended questions concerning the participants' observations on climate variation and change, trusted sources of information and preferred approaches to learning about climate change (see Appendix). The questions were modified for the rural educator group to take into account that educators are both recipients and providers of information. Finally, participants 
were asked to brainstorm and write down characteristics of an attractive educational program for people in their communities and to complete a short, anonymous survey about their focus group experience.

Each focus group discussion was audio recorded, transcribed, and coded by a research assistant using axial coding. Axial coding is a qualitative research method designed to sort, synthesize, and organize large amounts of data and reassemble them in new ways (Creswell \& Plano Clark, 2007). NVivo8 software was used to relate subcategories, specify the properties and dimensions of a category, and reassemble the data in ways that give coherence to the emerging analysis (Hiess-Biber \& Leavy, 2011). The focus group discussion data, responses to the Six Americas question, written suggestions from the brainstorming session, and responses to the post-meeting survey were examined collectively to identify and interpret important themes.

\section{Results and Discussion}

\section{Six Americas}

Figure 2 shows that our assumption regarding the wide spectrum of attitudes held by stakeholders was at least partly correct. Our participants did cover the Six Americas spectrum, although not all categories were equally represented. The majority of respondents in each group said that they felt "cautious" or "concerned" about climate change. Leiserowitz et al., (2010) had asked respondents about global warming rather than climate change, and reported a modal response of "concerned." Although the stakeholders in our focus groups were more cautious and less concerned, the results indicate that most focus group participants did not view themselves as disengaged, doubtful, or dismissive about climate change. Additionally, based on results from the post-focus group surveys, it appears that the Six Americas exercise and our approach to supporting the self-determination of stakeholders did create a safe space for substantive discussion. Ninety percent of the participants surveyed indicated they felt their voice was heard by the focus group facilitator, and $94 \%$ said they agreed that the meeting leaders remained neutral during the discussion. Furthermore, when asked what they appreciated most about the discussion, many open-ended comments referred to the ability to share and discuss a variety of viewpoints. "Everyone was heard and all opinions were valued," wrote one educator. 


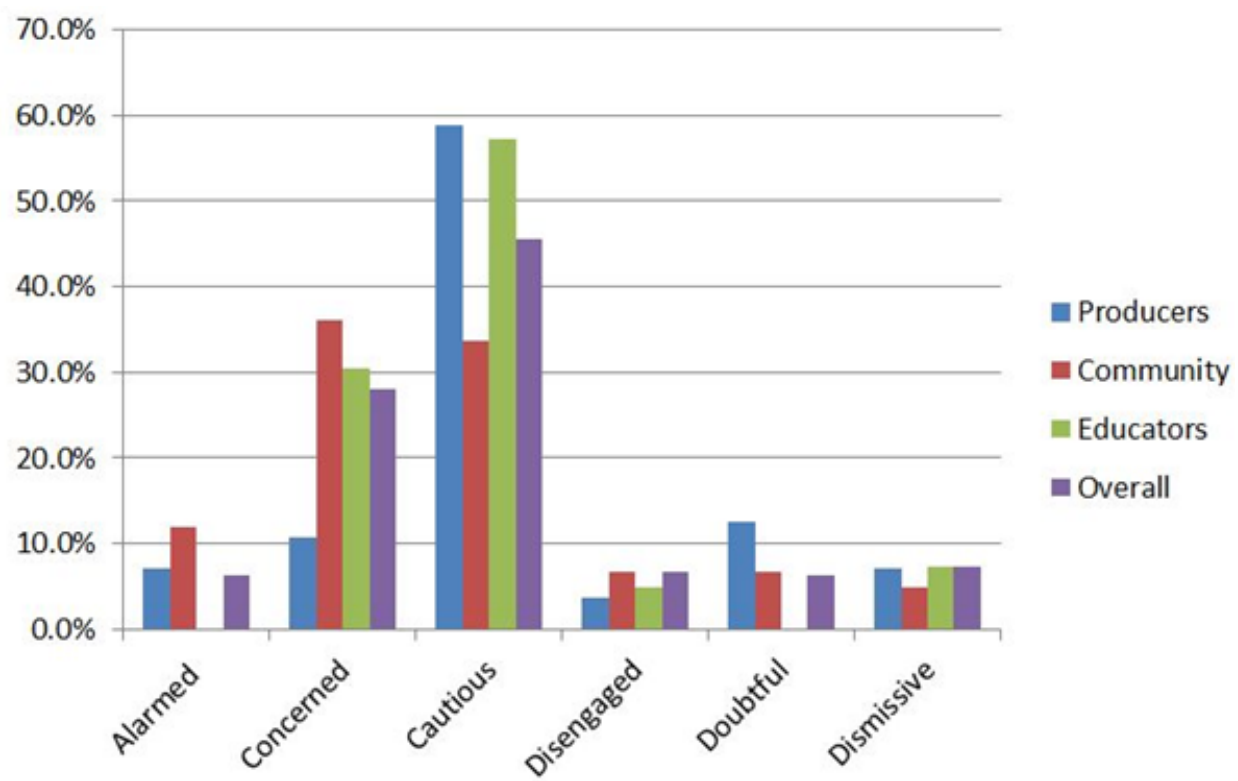

Figure 2: Distribution of Stakeholders across the "Six Americas" Categories

\section{Cross-cutting Unifying Themes}

As demonstrated by the "Six Americas" activity, focus group participants represented different perspectives. However, qualitative analysis of the transcripts revealed a number of common and unifying themes. The most prominent of these themes-trust, deliberative formats, personal and local relevance, and ease of access-suggest perspectives that should guide future educational efforts and raise a number of important research questions.

\section{Theme 1: Trust}

In every focus group, participants mentioned a desire for unbiased, trustworthy, non-political information. One agricultural producer mentioned, "We're trying to look for a nonbiased type of source of information...more than anything else." An educator similarly noted, "My biggest struggle...is what is true data and what is political hyped-up data, and trying to figure out which one's which." Similarly, a community member said, "there has been a perception out there...that [climate change] has been fabricated by academics to create a whole industry basically to keep them in the research dollars, and to fuel this whole green economy niche."

Although stakeholders wanted trustworthy information, there was evidence that some of their doubts and distrust might come from knowledge gaps. For example, many participants seemed to be unaware of the various scientific methods for studying climate. This lack of knowledge about such methods was exemplified by a community member who asked, "How can we say we know something about the climate before we had thermometers?" Similarly, a producer noted, "We've got a lot more sophisticated equipment now than 100 years ago, so who knows for sure if a thermometer back then that they're using is going to read the same as what the new ones would. It could be a one-degree difference...same with the carbon dioxide levels." Others seemed to place an overemphasis on discrete and short-term observations, such as a news report that a single glacier is growing, or observations of the temperature where they 
live, rather than global observations. Thus, a major challenge in providing information that seems trustworthy may lie in filling knowledge gaps.

When participants were asked whom they trusted as information providers, their answers were varied and sometimes contradictory. Trust in media and news programming was mixed, as was trust in government sources. The National Oceanic and Atmospheric Administration was generally trusted but the Environmental Protection Agency was viewed with more skepticism. University extension and local universities were well regarded as were climate science experts who stayed "non-political." Celebrities and special interest groups were generally distrusted, with Al Gore often cited as an example of someone distrusted.

The strong emphasis on issues of trust suggests that educational approaches to climate change also need to emphasize trustworthiness. There is a large and varied literature investigating trust in domains ranging from education (e.g., Hoy \& Tschannen-Moran, 2003; White-Cooper, Dawkins, Kamin, \& Anderson, 2009), political science (e.g., Cook \& Gronke, 2005; Hetherington, 1998), courts and other legally-relevant domains (Hamm et al., 2011; Tyler \& Huo, 2002), organization and management science (e.g., Bhattacharya, Devinney, \& Pillutla, 1998; Hardin, 2006; Moody, Galleta, \& Lowry, 2010), and many others (e.g., see reviews by Earle, 2010; Nannestad, 2008). Most of the work in these literatures focuses on the antecedents that appear to promote trust and confidence in people or institutions (e.g., institutions responsible for information delivery). The most commonly mentioned antecedents include perceptions of benevolence, competence, character (or integrity), and shared identity or values (Cvetkovich \& Nakayachi, 2007; Hoy \& Tschannen-Moran, 2003; Mayer, Davis, \& Schoorman, 1995).

When it comes to trust in climate and climate change educational programs, however, trust in information and technology also are likely to be important. Trust in information has been related to perceived accuracy and relevance, as well as to its presentation (e.g., how professional it seems). A number of authors also have noted that for information to impact personal actions, it needs to be perceived as salient, credible, and legitimate (Meinke et al., 2006; White et al., 2010). Others have discussed the need for and challenge of presenting transdisciplinary perspectives on sustainability and climate change in order to enhance both understanding and trust (Carter, 2008; Sharma, 2012). Meanwhile, the perceived trustworthiness of technology has been related to perceived technical competence, reliable and dependable performance, security, transparency, identification (e.g., Johnson, Bardhi, \& Dunn, 2007; McKnight, Choudhury, \& Kacmar, 2002; Patrick, Briggs, \& Marsh, 2005), familiarity, credibility, and the utility that the technologies afford (Bhattacherjee, 2002; Wang \& Benbasat, 2008). Distrust in technology, on the other hand, has been tied to factors such as unreliable performance and chaos (Johnson et al., 2007).

Such trust factors must be considered in the development of climate change educational programs and suggest a number of potentially important research questions. For example, when it comes to climate change information, what is most important: the trustworthiness of the information providers, the information, or the technology that captures climate data or is used to present climate data? Do certain aspects of trustworthiness or different bases of trust create greater barriers to or opportunities for learning? Are different educational methods and strategies (e.g., inquiry-based methods, perhaps?) more likely to overcome distrust? How can curriculum design enhance credibility and bring a greater diversity of interdisciplinary information sources together? Answers to these questions are important generally, but are especially relevant to topics such as climate change, which is characterized by considerable polarization and distrust.

\section{Theme 2: Deliberative Formats}

A second common theme appeared to be an outgrowth of trust issues: Participants wanted to decide who and what they trusted, and the implications of the information they received for themselves. "It would be great if we could get our hands on some unbiased facts and then we 
can decide what is best for our land," said one producer (emphases added). "Stick with the facts of 'okay this is what it is, this is what we mean by climate' and then go from there, let us make up our minds about the rest," said a community member. An educator commented, "That's why my kids [students] do the debating. They actually pick a side and debate that side and then I reverse it and have them research the opposite side. Just to show them there's so much conflicting data out there and that you have to build your own opinion."

The focus group participants' desire for information that helps them make up their own minds on issues of climate change supports our earlier-described choice to base focus group design on principles of self-determination. However, strategies for facilitating such self-determination within educational programs on climate change present a number of challenges. For example, evidence supports that people are "cognitive misers" (Fiske \& Taylor, 1991) and tend to use heuristics instead of careful analyses, especially about topics perceived as having less importance or about which they are less expert (Chaiken, 1980). Many researchers have suggested that deliberative models of public engagement may work against heuristic processing and promote more well-thought-out analyses. Public engagement in general and deliberative engagement specifically have been shown to enhance citizen-knowledge (Barabas, 2004; Fishkin \& Luskin, 2005), increase faith in democratic public institutions (Gastil, 2000), enhance personal and political efficacy (Button \& Ryfe, 2005), and result in informed public input into policy (Farrar et al., 2010). Nonetheless, there is not yet a strong research base for how to best structure such engagements for specific purposes or to achieve specific outcomes (e.g., see review by PytlikZillig \& Tomkins, 2011). The communicative choices and arguments that lead to high-quality deliberations are also relatively unexamined (Steffensmeier \& Schenck-Hamlin, 2008), and some negative outcomes even have been reported (e.g., Sanders, 1997).

In summary, many questions remain regarding whether, when, and how to engage citizens and students in deliberations of complex scientific topics. When it comes to designing deliberative events, we need to understand how best to introduce scientific expertise into them and how socio-cultural issues influence the deliberative and participatory processes (Peterson et al., 2010). To structure the content of deliberative engagements, we need to explore how to assess the "quality" of deliberative exchanges and understand when deliberation might introduce or support misconceptions rather than more accurate understandings. In addition, more research is needed to determine how deliberations influence personal efficacy and involvement (LaFasto \& Larson, 2012), particularly when focused on complex scientific topics.

\section{Theme 3: Personal and Local Relevance}

A third theme that emerged across stakeholder groups was a desire for information that was personally and locally relevant. For example, one producer mentioned that "...someone in western Kansas isn't overly concerned that the average temperature has increased for New York State." Another producer acknowledged the importance of global views but still stressed the preeminence of local information: "We're much more global than we used to be...but when it comes down to it, it's at your own table and how it affects you in your own hometown that is very important." Likewise, a community member noted that information should be "more local instead of looking at the bigger global issue." This person added, "I think people personally want to know what is going on at home." A city council member commented, "Climate affects everything that our city does-from the number of days that the swimming pool is closed to the number of rain delays we have on ball games to the amount of money that it takes us to shovel snow every year and the salt that we use to do that." Other community members echoed this perspective, advising the CEP researchers to "talk about prevailing conditions in an area-drought in central Kansas, how will the predicted changes affect regional economy/businesses?" 
Research and theory related to place-based education (e.g., Gruenewald \& Smith, 2008) seems especially relevant to the focus group participants' call for locally-relevant information. According to Semken (2012, p. 2641), "Place-based curriculum and instruction is primarily intended to motivate students through humanistic and scientific engagement with surroundings and to promote sustainability of local environments and communities... and only secondarily to meet specific disciplinary standards or achievement tests." Provision of locally-relevant information has been linked to the need to teach rural children how "to live well in their own communities;" and place-based education has been contrasted with contemporary schooling, which some argue is based on curricula that strip knowledge from its context and teach separateness rather than connectedness (Haas \& Nachtigal, 1998). Furthermore, initial investigations suggest place-based education may be a promising method for both enhancing the motivation and learning of some students, as well as having potential benefits for community problemsolving by involving teachers and students in such processes (Smith \& Sobel, 2010).

The desire of focus group members for locally- and personally-relevant information also fits with empirical research from the learning sciences demonstrating the powerful engagement effects of contextualization, personalization, and choice (Cordova \& Lepper, 1996). Personalization, or increasing the personal relevance of information, is also a common strategy for increasing depth of cognitive processing and cognitive elaboration in experimental studies on attitudes and persuasion (Petty \& Cacioppo, 1986; Tormala \& Petty, 2004). Relevance can be defined in terms of the consequences that an issue has for a person and is thought to increase motivation to process information (Petty \& Cacioppo, 1986), which may also enhance learning. Personal and local relevance has also been discussed in relation to the framing of issues, with researchers and practitioners alike pointing to such relevancies as potential strategies for presenting information in a manner that resonates with different stakeholders (Nisbet, 2009; Zia \& Todd, 2010). Increased motivation to think carefully about topics, however, does not guarantee a certain outcome. For example, studies have shown that under high personal relevance conditions, strong and believable evidence and information will be quite persuasive; while weaker and less believable evidence might not only fail to convince, but also create subsequent resistance to belief in a given claim (Tormala \& Petty, 2004). In addition, Yarnal and colleagues (Yarnal, O'Connor, \& Shudak, 2003) found that use of a local rather than national frame for consideration of climate change and economic issues, resulted in survey respondents indicating less willingness to support mitigation efforts.

As the just reviewed theoretical and empirical work suggests, construction of locally- and personally-relevant climate change information needs to be conducted carefully, and the impacts of such information tested thoroughly to ensure that such information achieves its potentially positive effects. In addition, research is needed to better understand the mechanisms by which personally- and/or locally-relevant information may be beneficial. For example, is locally-relevant place-based information effective because it is personally relevant? Or does local relevance contribute above and beyond personal relevance? To what extent, if any, are the impacts of personal and local relevance mediated by increasing trust in the information? Is local relevance more important for some groups than others? Are there some conditions under which or outcomes for which novelty (and non-local information) is more effective than locally-relevant information?

\section{Theme 4: Ease of Access}

Finally, a fourth theme that emerged in the focus group discussions pertained to the difficulty of accessing desired climate information. Although there was general agreement among focus group participants that there was too much rather than too little information available about climate change, many of the quotes indicated that the stakeholders did not know how to access the locally-specific and trustworthy information they wanted. One producer noted, "We're 
getting so much information, it's like, all right, we've got a vast source of scientific information, now how do we narrow it down a little bit into specific scientific areas that can be user friendly for us?" "There are so many tools out there. At least narrow it down so four people aren't looking at four different sites trying to figure out what to do in the next three days and plan priorities," said another producer. Yet another producer observed, "K-State has a link, NOAA has a link, National Weather Service has a link, every television station has a link... Could there be something that more or less pulled those commonalities of databases together that was easy for the general public to use?" In addition, different stakeholders needed information for different purposes, which suggested that the information needs to be integrated, embedded and presented in different formats and contexts. For example, an educator requested, "maybe putting a few questions together, like a handout sheet...guided notes to go along with the lesson, and even a quiz... Realistically that's used a lot more than if we have to do it ourselves because it's just hard to find the time."

Participants' comments pertaining to the accessibility of information, including the drawbacks of having too much information of varying (but often unknown) quality and the need for the right types and formats of information for different purposes, brings to bear a number of theories of decision making, and diffusion of innovation, technology, and knowledge transfer. For example, research in social psychology has found that an increased number of choices beyond a certain point can decrease the probability of making any choice at all, as well as decreasing satisfaction with one's choice (Iyengar \& Lepper, 2000). The likelihood of increased choices undermining motivation to choose may be especially powerful when consumers are uncertain about what they want or what constitutes quality (Chernev, 2003). Similarly, theories of acceptance and diffusion, such as the technology acceptance model and innovation diffusion theory (Davis, 1989; Rogers, 1995), stress the importance of perceived usefulness, ease of use (vs. complexity), and relative advantage provided by the innovation, as well as compatibility with values, observability, and ability to try out the innovation before committing to it.

Once again, considering the statements made by the focus group participants in light of these theories raises a number of important questions. For example, what does "ease of access" really mean to specific stakeholders? How are perceptions of easy access influenced by the medium (e.g., web-based versus print materials, accessibility with mobile devices) and the content, which will vary for different audiences and purposes? Furthermore, to what extent does the satisfaction of such specific demands, enhance versus limit motivation to learn about and understand climate science? For example, if producers are given answers to their central questions (e.g., risks associated with certain seed choices), will this decrease or increase interest in the science behind the information? Other important questions pertain to prior attempts to create useful and usable clearinghouses of climate science educational materials. Cleannet.org and Camelclimatechange. org are two existing clearinghouses of resources for educators. What are the barriers keeping educators from using those existing resources? Given the concern with trustworthy information and the desire to "decide for themselves" expressed by focus group members, to what extent does the translation of climate information into easy to use formats actually erode trust in the information? Finally, is it possible to simultaneously enhance trust, deliberation of information, personal and local relevance and ease of access? Or does the enhancement of certain factors work against others?

\section{Conclusion}

The design of our focus groups to engage and support the self-determination of stakeholders reflects the perspective that it is not enough to merely identify techniques for increasing acceptance of climate information. Effective educational programs should foster rich engagement with climate information as it relates to these cognitive, social, and cultural forces and facilitate stakeholders in responding proactively regarding the impacts of climate change on their futures. 
As we used these methods to explore CGP stakeholders' views on educational programming they would find meaningful, we discovered that very few focus group members were disengaged or dismissive about the issue of climate change. While they may not have been actively engaged with adaptation or mitigation efforts, they reported being cautious and concerned about how climate change might impact them and interested in learning more about climate change topics. They also expressed some clear preferences for how they wanted to engage with such issues. They sought trustworthy, non-biased, non-political, locally- and personally-relevant information; they wanted to be empowered to make their own decisions rather than told what to do; and they wanted access to information that is both more useful and usable. The themes that emerged from the focus groups not only provide direction for developing effective climate change education programs in the CGP, but also demonstrated the need and desire for such climate change education.

The data collected and reported in this article provides several hints regarding what CGP stakeholders are looking for when it comes to information about climate and climate change. The overarching themes of trust, deliberation, ease-of-access, and relevance, are quite likely to be important across cultures and countries; indeed, many of the articles cited in this paper touch upon these themes. However, in accordance with Nisbet's call for further exploration, identification and testing, we also made progress exploring and identifying some specific details that might show promise for improving regionally-targeted educational efforts. For example, the quotes in this paper identify specific trust-related concerns, such as whether academics might be fabricating results or exaggerating claims; specific knowledge gaps that may act as barriers to fruitful deliberation; lists of specific websites that residents wished could be integrated and summarized for easier access; and ideas for specific regional concerns of interest and relevance to residents. There is still a need, of course, to test whether the specifics identified in our focus groups do generalize to the larger target populations. Future research is also needed to explore how the general themes reported in this article vary in their application to specific stakeholder groups, and to explore the application of numerous theories which might provide useful guidance for climate change educational planning efforts. Theories related to public trust, deliberation and social engagement, locally- and personally-relevant content, and ease of information access are likely to be important components of a framework for ensuring more effective regional climate education.

\section{Author Note}

Please direct inquiries regarding this article to the corresponding authors, Lisa PytlikZillig or Tim Steffensmeier.

This research was supported by NSF-CCEP \#1135395, Central Great Plains Climate Change Education Partnership. Portions of this research were presented as part of a workshop at the Eighth International Conference on Environmental, Cultural, Economic and Social Sustainability, held at the University of British Columbia, Vancouver, Canada, 10-12 January 2012. The authors would like to thank the workshop participants who provided feedback on many of the ideas in this article. The authors also acknowledge and greatly appreciate the assistance of Melanie Pechanec and staff at the Office of Educational Innovation and Evaluation (OEIE) at Kansas State University, for their help analyzing data and preparing figures; and Alan Tomkins and Nancy Shank for their comments on earlier drafts of this article. 


\section{REFERENCES}

Barabas, J. (2004). How deliberation affects policy opinions. American Political Science Review, 98, 687-701.

Bhattacharya, R., Devinney, T. M., \& Pillutla, M. M. (1998). A formal model of trust based on outcomes. Academy of Management Review, 23, 459-472.

Bhattacherjee, A. (2002). Individual trust in online firms: Scale development and initial test. Journal of Management Information Systems, 19(1), 211-241.

Bostrom, A., Morgan, M. G., Fischhoff, B., \& Read, D. (1994). What do people know about global climate change? 1. Mental models. Risk Analysis, 14, 959-970.

Button, M., \& Ryfe, D. (2005). What can we learn from the practice of deliberative democracy? In J. Gastil \& P. Levine (Eds.), The deliberative democracy handbook: Strategies for effective civic engagement in the $21^{\text {st }}$ century (pp. 20-33). San Francisco: Jossey Bass.

Carter, L. (2008). Sociocultural influences on science education: Innovation for contemporary times. Science Education, 92(1), 165-181.

Chaiken, S. (1980). Heuristic versus systematic information processing and the use of source versus message cues in persuasion. Journal of Personality and Social Psychology, 39, $752-766$.

Chernev, A. (2003). When more is less and less is more: the role of ideal point availability and assortment in consumer choice. Journal of Consumer Research, 30, 170-183.

Cook, T. E., \& Gronke, P. (2005). The skeptical American: Revisiting the meanings of trust in government and confidence in institutions. The Journal of Politics, 67, 784-803.

Cordova, D. I., \& Lepper, M. R. (1996). Intrinsic motivation and the process of learning: benefits of contextualization, personalization, and choice. Journal of Educational Psychology, 88, 715-730.

Creswell, J. W., \& Plano Clark, V. L. (2007). Mixed methods research. London: Sage.

Cvetkovich, G., \& Nakayachi, K. (2007). Trust in a high-concern risk controversy: A comparison of three concepts. Journal of Risk Research, 10, 223-237.

Davis, F. D. (1989). Perceived usefulness, perceived ease of use, and user acceptance of information technology. MIS Quarterly, 13, 319-340.

Deci, E. L., \& Ryan, R. M. (1987). The support of autonomy and the control of behavior. Journal of Personality and Social Psychology, 53, 1024-1037.

Deci, E. L., \& Ryan, R. M. (2000). The "what" and "why" of goal pursuits: Human needs and the self-determination of behavior. Psychological Inquiry, 11, 227-268.

Dunlap, R. E., \& McCright, A. M. (2008). A widening gap: Republican and Democratic views on climate change. Environment, 50(September/October), 26-35.

Dupigny-Giroux, L.-A. L. (2010). Exploring the challenges of climate science literacy: Lessons from students, teachers and lifelong learners. Geography Compass, 4(9), 1203-1217. doi: 10.1111/j.1749-8198.2010.00368.x

Earle, T. C. (2010). Trust in risk management: A model-based review of empirical research. Risk Analysis, 30(4), 541-574.

Edelson, D. C. (2001). Learning-for-use: a framework for the design of technology-supported inquiry activities. Journal of Research in Science Teaching, 38, 355-385.

Farrar, C., Fishkin, J., Green, D., List, C., Luskin, R., \& Paluck, E. (2010). Disaggregating deliberation's effects: An experiment within a deliberative poll. British Journal of Political Science, 40, 333-347.

Fishkin, J., \& Luskin, R. (2005). Experimenting with a democratic ideal: Deliberative polling and public opinion. Acta Politica, 40, 284-298.

Fiske, S. T., \& Taylor, S. E. (1991). Social cognition. New York: McGraw-Hill.

Fiskin, J. (1991). Democracy and deliberation. New Haven: Yale University Press.

Gastil, J. (2000). By popular demand. Berkeley: University of California Press. 
Gruenewald, D. A., \& Smith, G. A. (2008). Place-based education in the global age: Local diversity. New York: Lawrence Erlbaum Associates.

Haas, T., \& Nachtigal, P. M. (1998). Place value: an educators' guide to good literature on rural lifeways, environments, and purposes of education. Charleston, West Virginia: ERIC Clearinghouse on Rural Education and Small Schools.

Hamm, J. A., PytlikZillig, L. M., Tomkins, A. J., Herian, M. N., Bornstein, B. H., \& Neeley, E. (2011). Exploring separable components of institutional confidence. Behavioral Sciences and the Law, 29, 95-115.

Hardin, R. (2006). The street-level epistemology of trust. In R. M. Kramer (Ed.), Organizational trust: A reader (pp. 21-47). New York: Oxford University Press.

Harrington, J., Jr. (2008). Misconceptions: Barriers to improved climate literacy. Physical Geography, 29, 575-584.

Hetherington, M. J. (1998). The political relevance of political trust. American Political Science Review, 92, 791-808.

Hiess-Biber, S. H., \& Leavy, P. (2011). The practice of qualitative research. Thousand Oaks, CA: Sage Publications.

Hoffman, M., \& Barstow, D. (2007). Revolutionizing earth system science education for the $21^{\text {st }}$ century, report and recommendations from a 50-state analysis of earth science education standards (pp. 59). Cambridge, MA: TERC.

Hoy, W. K., \& Tschannen-Moran, M. (2003). The conceptualization and measurement of faculty trust in schools: The omnibus T-Scale. In W. K. Hoy \& C. Miskel (Eds.), Studies in leading and organizing schools (pp. 181-208). Greenwich, CT: Information Age Publishing.

Iyengar, S. S., \& Lepper, M. R. (2000). When choice is demotivating: Can one desire too much of a good thing? Journal of Personality and Social Psychology, 79, 995-1006.

Johnson, D., Bardhi, F., \& Dunn, D. (2007). The role of technology paradoxes in customer satisfaction evaluation of self-service technology. Paper presented at the 2007 AMA Winter Educators' Conference: Marketing Theory and Applications, Chicago, IL.

LaFasto, F., \& Larson, C. (2012). The humanitarian leader in each of us: 7 choices that shape a socially responsible life. Thousand Oaks, CA: Sage Publishers, Inc.

Leiserowitz, A. (2006). Climate change risk perception and policy preferences: the role of affect, imagery, and values. Climatic Change, 77(1-2), 45-72.

Leiserowitz, A. (2009). Risk perceptions and behavior. In S. H. Schneider, A. Rosencranz, M. D. Mastrandrea \& K. Kuntz-Duriseti (Eds.), Climate change science and policy (pp. 175-184). Washington, D.C.: Island Press.

Leiserowitz, A., Maibach, E., Roser-Renouf, C., Smith, N., \& Hmielowski, J. D. (2011). Climate change in the American mind: Americans' global warming beliefs and attitudes in November 2011. New Haven, CT: Yale Project on Climate Change Communication: Yale University and George Mason University.

Leiserowitz, A., \& Smith, N. (2010). Knowledge of climate change across global warming's six Americas. New Haven, CT: Yale University.

Leiserowitz, A., Smith, N., \& Marlon, J. R. (2010). Americans' knowledge of climate change. New Haven, CT: Yale Project on Climate Change Communication: Yale University.

Mayer, R. C., Davis, J. H., \& Schoorman, F. D. (1995). An integrative model of organizational trust. Academy of Management Review, 20, 709-734.

McCright, A. M., \& Dunlap, R. E. (2011). The politicization of climate change: Political polarization in the American public's views of global warming. Sociological Quarterly, 52, 155-194.

McKnight, D. H., Choudhury, V., \& Kacmar, C. (2002). Developing and validating trust measures for e-commerce: An integrative typology. Information Systems Research, 13(3), 334-359. 
Meinke, H., Nelson, R., Kokic, P., Stone, R., Selvaraju, R., \& Baethgen, W. (2006). Actionable climate knowledge: From analysis to synthesis. Climate Research, 33, 101-110.

Milér, T., \& Sládek, P. (2011). The climate literacy challenge. Procedia Social Behavioral Sciences, 12, 150-156.

Moody, G. D., Galleta, D. F., \& Lowry, P. B. (2010). Unifying conflicting models of trust and distrust for enhanced understanding and predictive power in organizational relationships: Proposing the unified trust-distrust model. Sprouts: Working Papers on Information Systems, 10(68), 10-68.

Nannestad, P. (2008). What have we learned about generalized trust, if anything? Annual Review of Political Science, 11, 413-436.

Nisbet, M. C. (2009). Communicating climate change: Why frames matter to public engagement. Environment, 51(2), 514-518.

Nisbet, M. C., \& Mooney, C. (2007). Framing science. Science, 316, 56.

Patrick, A. S., Briggs, P., \& Marsh, S. (2005). Designing systems that people will trust. In L. F. Cranor \& S. Garfinkel (Eds.), Security and usability: Designing secure systems that people can use (pp. 75-99). Sebastopol, CA: O'Reilly Media, Inc.

Peterson, N., Broad, K., Orlove, B., Roncoli, C., Taddei, R., \& Velez, M. (2010). Participatory processes and climate forecast use: Socio-cultural context, discussion, and consensus. Climate and Development, 2, 14-29.

Petty, R. E., \& Cacioppo, J. T. (1986). The elaboration likelihood model of persuasion. Advances in Experimental Social Psychology, 19, 123-192.

PytlikZillig, L. M., \& Tomkins, A. J. (2011). Public engagement for informing science and technology policy: What do we know, what do we need to know, and how will we get there? Review of Policy Research, 28, 197-217.

Rachlinski, J. J. (2000). The psychology of global climate change. University of Illinois Law Review, 1, 299-319.

Rogers, E. M. (1995). Diffusion of innovations (Fourth ed.). New York: The Free Press.

Sanders, L. M. (1997). Against deliberation. Political Theory, 25, 347-376.

Semken, S. (2012). Place-based teaching and learning. In N. M. Seel (Ed.), Encyclopedia of the sciences of learning (pp. 2641-2642). New York: Springer.

Sharma, A. (2012). Global climate change: What has science education got to do with it? Science \& Education, 21, 33-53.

Smith, G. A., \& Sobel, D. (2010). Place- and community-based education in schools. New York: Routledge.

Smith, J. B., Schneider, S. H., Oppenheimer, M., Yohe, G. W., Hare, W., Mastrandrea, M. D., ... Ypersele, J.-P. v. (2009). Assessing dangerous climate change through an update of the Intergovernmental Panel on Climate Change (IPCC) "reasons for concern". Proceedings of the National Academy of Sciences of the United States of America. doi: 10.1073/pnas.0812355106

Steffensmeier, T., \& Schenck-Hamlin, W. (2008). Argument quality in public deliberations. Argmentation and Advocacy, 45, 21-36.

Talpin, J., \& Wojcik, S. (2010). Deliberating environmental policy issues: comparing the learning potential of online and face-to-face discussions on climate change. Policy \& Internet, 2(2), 61-93.

Tormala, Z. L., \& Petty, R. E. (2004). Resistance to persuasion and attitude certainty: The moderating role of elaboration. Personality and Social Psychology Bulletin, 30(11), $1446-1457$.

Tyler, T. R., \& Huo, Y. J. (2002). Trust in the law: Encouraging public cooperation with the police and courts. New York: Russell-Sage Foundation.

Uherek, E., \& Schüpbach, E. (2008). European efforts in earth science and climate change education. Physical Geography, 29, 545-560. 
United Nations Economic Commision for Africa African Climate Policy Centre (2011). Climate change and water in Africa: Analysis of knowledge gaps and needs.

Wang, W., \& Benbasat, I. (2008). Attributions of trust in decision support technologies: A study of recommendation agents for e-commerce. Journal of Management Information Systems, 24(4), 249-273.

White-Cooper, S., Dawkins, N. U., Kamin, S. L., \& Anderson, L. A. (2009). Community-institutional partnerships: Understanding trust among partners. Health Education and Behavior, 36, 334-347.

White, D. D., Wutich, A., Larson, K. L., Gober, P., Lant, T., \& Senneville, C. (2010). Credibility, salience, and legitimacy of boundary objects: Water managers' assessment of a simulation model in an immersive decision theater. Science and Public Policy, 37, 219-232.

Wynne, B. (1995). Public understanding of science. In S. Jasanoff, G. E. Markle, J. C. Petersen \& T. Pinch (Eds.), Handbook of science and technology studies (pp. 361-388). Thousand Oaks, CA: Sage.

Yarnal, B., O'Connor, R. E., \& Shudak, R. (2003). The impact of local versus national framing on willingness to reduce greenhouse gas emissions: A case study from central Pennsylvania. Local Environment, 8, 457-469.

Zia, A., \& Todd, A. M. (2010). Evaluating the effects of ideology on public understanding of climate change science: How to improve communication across ideological divides? Public Understanding of Science, 19, 743-761.

Ziman, J. (1991). Public understanding of science. Science, Technology \& Human Values, 16, 99-105.

Ziman, J. (1992). Not knowing, needing to know, and wanting to know. In B. V. Lewenstein (Ed.), When science meets the public (pp. 13-20). Washington: American Association for the Advancement of Science.

\section{Appendix: Focus Group Questions}

\section{Community and Producer Groups:}

1) What have been your observations about variations in climate in the last decade?

How have you been impacted by variations in climate?

In what ways, if any, have you responded to the variations in climate?

2) What are the common beliefs and values (or concerns) about trends in weather and climate variation that apply to people across the spectrum?

3) What kinds of information or resources would you like to know about climate variability? What resources and information are important to people in this group?

4) What sources of information regarding climate variations do you use and trust?

5) What are the approaches to talking about climate change that you do appreciate?

What are the approaches to talking about climate change that you don't appreciate?

\section{Educator Groups:}

1. Where is climate addressed in your curriculum?

What specific courses include this material?

What grade level are those courses?

Do the current curriculum standards get in the way or offer an entry point for climate education?

2. What are you doing to teach climate change in these courses?

Are you including local climate date in your courses?

3. What kind of information do you need to improve your understanding of climate change?

4. What kinds of materials would you prefer to teach climate change? 
What sources of information do you use and trust?

5. What would be the best way to get this information to you?

6. What concerns have there been by your school system or community about including climate change in your curriculum?

\section{ABOUT THE AUTHORS}

Lisa M. PytlikZillig: Lisa PytlikZillig is a Research Assistant Professor at the University of Nebraska Public Policy Center. Her research focuses on understanding and improving public engagement with governmental policy. As part of that work, she has used experimental designs to examine trust in institutions, methods for effectively communicating complex information (including science) to the public, and the relationships between "participant engagement" and different features of public engagement.

Tim Steffensmeier: Dr. Timothy Steffensmeier is an Associate Professor and Head of the Department of Communication Studies at Kansas State University. In addition he serves as a research associate with the Institute for Civic Discourse and Democracy. He has a Ph.D. in Communication Studies. His research interests include rhetorical invention, deliberative democracy and argumentation as they contribute to sustainable community development.

Amber Campbell Hibbs: Amber Campbell Hibbs is the Project Coordinator for the Central Great Plains Climate Education Partnership (CGP-CEP) and the Kansas NSF EPSCoR Climate Change Mitigation Project as well as an Adjunct Assistant Professor of Anthropology at Kansas State University. Her research examines the influence of human interaction with the environment through food production and the impacts of those interactions on health and wellbeing. She was awarded a National Science Foundation Graduate Research Fellowship and received a Ph.D. in Biocultural Anthropology from Emory University in 2010. She has conducted research on the influence of irrigation use patterns on disease transmission dynamics in archaeological populations and is currently developing climate education programs for rural populations including agricultural producers in Kansas and Nebraska as part of the Central Great Plains Climate Education Partnership.

Benjamin L. Champion: Ben Champion is director of sustainability for Kansas State University, and also holds the title of assistant professor of geography. In this role, he leads university-wide initiatives to address sustainability through campus operations and administration, student life, curriculum development, research collaborations, and outreach. His past research has focused on North American local food movements and his current research interests include the political economies of food and energy systems, community planning, community climate adaptation strategies, and communication and education challenges of climate change.

Eric Hunt: Eric Hunt is a Ph.D. candidate in Natural Resources Sciences with a specialization in Bio-atmospheric interactions at the University of Nebraska-Lincoln. His research focuses on the seasonal relationship of soil water under rainfed and irrigated agroecosystems, the relationship of soil water and evapotranspiration, and the relationship of soil water with other biophysical parameters. Eric has a strong interest in doing Extension related work with agricultural producers on issues such as climate change.

John Harrington, Jr.: John Harrington, Jr. is a Professor and former Department Head in the Department of Geography at Kansas State University. His research and teaching interests include the human dimensions of global change, remote sensing of land cover change, climate science, 
GIScience applications in local resource management, and geographic education. Dr. Harrington, Jr. has considerable experience working on interdisciplinary teams to address research questions related to challenges associated with coupling natural and human systems.

Jacqueline D. Spears: Jacqueline Spears is a Professor of Curriculum and Development. She current directs the Center for Science Education and serves as the Interim Associate Dean for Academic Programs and Research at the Olathe Innovation Campus. She completed both B.S. and M.S. degrees in Physics prior to completing doctoral work in Curriculum and Instruction. Her areas of expertise include educational programs serving rural populations, gender issues in education, and strategies for linking Science, Technology, Engineering, and Mathematics (STEM) education in the university with K-12 classrooms.

Natalie Umphlett: Natalie Umphlett is the regional climatologist at the High Plains Regional Climate Center, which is located within the School of Natural Resources at the University of Nebraska-Lincoln. In addition, she serves as an assistant for the adult education program called Climate Masters of Nebraska. She received a M.S. in Geosciences, with an emphasis in Meteorology-Climatology from the University of Nebraska-Lincoln in 2008. Her research and service interests are focused on high plains climatology and climate/climate change education with an emphasis on rural and native communities. She has worked for the Center since 2008.

Tarik Abdel-Monem: Tarik Abdel-Monem is a Research Specialist at the University of Nebraska Public Policy Center. He has helped coordinate or evaluate a variety of public engagement programs and activities in Nebraska, and nationally. He received a Juris Doctorate and Master's in Public Health from the University of Iowa.

Roger Bruning: Roger Bruning, Ph.D, is Velma Warren Hodder Professor of Educational Psychology and Co-Director of the Center for Instructional Innovation at the University of Nebraska, Lincoln (UNL), where he teaches courses in applied cognitive psychology, cognition and technology, and motivation. He has served as a principal investigator and consultant for numerous education- and science-related projects and as evaluator for major projects of the National Science Foundation, Howard Hughes Medical Institute, Agency for International Development, and Environmental Protection Agency. He is the primary developer of two online learning tools: ThinkAboutIt, which uses participant judgments and structured interactions to develop critical thinking, and InfoGather, which helps users assemble online information in ways promoting deep learning. Bruning's research has tested features of online applications in context ranging from video case utilization in medical and teacher education to farmers' use of satellite data in making water-use decisions. He is serving or has served as an editorial board member for the Journal of Educational Psychology, Contemporary Educational Psychology, Scientific Studies in Reading, and Educational Psychology Review. A member of AAAS and Sigma Xi, he is a Fellow of the American Psychological Association and the American Educational Research Association.

Daniel W Kabl: Daniel Kahl serves as the Extension Liaison with the KSU Center for Engagement and Community Development. As Liaison, he connects research, education, and outreach projects of the university with the work of Extension professionals across the state. In addition, the work connects relevant community development concerns with university resources. Through his work as the Director of the Kansas PRIDE Program, he assists community-based volunteer groups to mobilize for community betterment. Dan also assists with the design and offering of Extension Professional Development opportunities, including work through the Institute for Civic Discourse and Democracy on Public Issues Forums Facilitation; the Kansas Environmental Leadership Program; Community Coaching, and; Community Development Academies. Dan has a Master's Degree in Leadership Studies, and a Ph.D. Adult Education. 

The International Journal of Sustainability Education is one of four thematically focused journals in the family of journals that support the Sustainability knowledge community-its journals, book series, conference, and online community. It is a section of The International Journal of Environmental, Cultural, Economic and Social Sustainability.

The journal explores teaching and learning about human relations to the environment. It also investigates community education and the challenge of raising public awareness about sustainability.

In addition to traditional scholarly papers, this journal invites presentations of practice-including documentation of curricular practices and exegeses analyzing the effects of those practices.

The International Journal of Sustainability Education is a peer-reviewed scholarly journal.

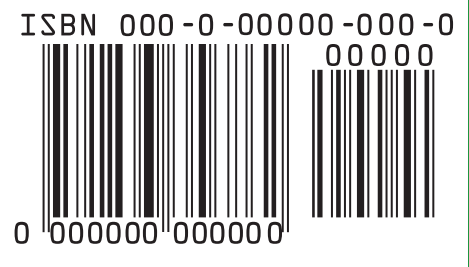

